\title{
The viability of Trichinella spiralis larvae in frozen pork and wild boar meat revealed by the experimental infection of laboratory mice
}

\author{
O. C. IACOB \\ Faculty of Veterinary Medicine lași, 8, Mihail Sadoveanu Alley, 700489, Romania, \\ E-mail: oiacob@uaiasi.ro, iacobolimpia@yahoo.com
}

\section{Article info}

Received July a8, 2014 Accepted December 2, 2014

\begin{abstract}
Summary
The aim of the research was to verify the viability of Trichinella spiralis larvae in pig and wild boar meat frozen at $-18^{\circ} \mathrm{C}$ from 268 days to 1021 days.

There were three groups of laboratory inbred Balb/C mice and Bagg/ Albino/ strain C, each group received one sample consisting of $20 \mathrm{~g}$ meat infected with $T$. spiralis larvae, according to the protocol, and an uninfected control group. The experiments were ended after 80 days, by euthanizing the mice and taking samples of muscle tissue, which were processed for histopathology. The results revealed the presence of Trichinella cysts in all experimental groups, confirming the extraordinary durability and viability of Trichinella larvae in meat frozen at $-18^{\circ} \mathrm{C}$ for many months. It was confirmed that the larvae detected in muscle tissues of mice were Trichinella spiralis.
\end{abstract}

Keywords: Trichinella spiralis; frozen meat; viability; infection; mice

\section{Introduction}

Trichinella spp. are some of the most widespread parasites infecting people and other mammals all over the world, regardless of climate (Dupouy-Camet, 2000). The etiological agents of human trichinellosis show virtually worldwide distribution in domestic and/ or sylvatic animals, with the exception of Antarctica, where there is neither a record of this nematode nor evidence of any epidemiological study. This global distribution of Trichinella spp. is in conjunction with varying cultural eating habits, represent the main factor favouring human infections (Pozio \& Zarlenga, 2005). The global prevalence of the human trichinellosis is difficult to evaluate but as many as 11 million people may be infected (Dupouy-Camet, 2000; Kapel, 2005).

The Trichinella genus includes 8 species (T. spiralis, T. nativa, $T$. britovi, T. nelsoni, T. murrelli, T. pseudospiralis, T. papuae, T. zimbabwensis) and many genotypes (Trichinella T5, T6, T8, T9, T12) not yet accredited to any species. The parasite's ability to infect people worldwide is well documented (Murrell et al., 2000; Pozio \& Zarlenga, 2005; Krivokapich et al., 2008; Pozio et al., 2009). Two main clades are recognized in the genus Trichinella; one that encompasses species that encapsulate in host muscle tissue, and a second that does not encapsulate following muscle cell dedifferentiation (Pozio \& Zarlenga, 2005).

Trichinella spiralis (Owen, 1835) is the only species usually found in porcine, and some wild animals (e.g, boar, bear, carnivores, rodents). T. spiralis can be transmitted and maintained in both a domestic and sylvatic cycle whereby rats, among others contribute to the spread of $T$. spiralis from domestic to sylvatic animals and vice versa (Pozio, 2007; Farina et al., 2012). The only means of transmission is through the ingestion of infected, striated muscle tissue. The natural reservoirs of Trichinella species are wild carnivorous and omnivorous animals (Pozio, 2005).

The distribution area of $T$. spiralis has been strongly influenced by the passive introduction of this pathogen by domestic pigs and synanthropic rats. The broad host spectrum. Trichinella should be considered when implementing measures for avoiding the transmission from animals to humans (Pozio, 2001). Homo sapiens is the only species (of Primates) that has been found to be naturally-infected with all species of Trichinella, except T. zimbabwensis (Pozio, 2001).

When humans fail to manage properly food animals or to control the interface between wild and domestic animals, transmission of some species (i.e. T. spiralis, T. britovi and T. pseudospiralis) can 
occur between these hosts. This transmission route inevitably involves pigs (Pozio \& Murrell, 2006).

The emergence of trichinellosis in some countries is explained by a better knowledge of the disease (formerly often misdiagnosed as influenza), modifications of consumer habits, re-forestation in Europe and increase of wild game, importation of meats from countries where trichinellosis is endemic and failure of veterinary control due to human error or to social upheavals. This disease linked to meat-consumption, which is theoretically easy to prevent by adequate cooking, freezing and veterinary controls, should deserve the attention of all persons involved in public health and it could be eradicated at least from domestic pigs (Dupouy-Camet, 2000; Paraličová et al., 2013).

There is the possibility of farm animals to get infection from rats or other infected material being hazardously mixed with hay or other feed. If silage is stored for at least one month before use, however, the risk from this forage appears to be minimized (Oivanen et al., 2002).

Trichinellosis continues to represent a major concern in Romania where the following species have been identified: $T$. spiralis in the synanthropic and sylvatic environment and T. britovi, T. pseudospiralis in the sylvatic one (Blaga et al., 2009). During the years 2007 - 2009, Romania has reported to the WHO's Regional Office for Europe the highest incidence of trichinellosis in humans. During this period, the yearly average incidence of human trichinellosis was 2.7 cases per 100000 inhabitants (Neghină et al., 2012).

Until now, in Romania, in the external environment, Trichinella cysts of cadavers may survive putrefaction and desiccation for up to four months (Cironeanu \& Ispas, 2002) as well as climate factors such as temperature, humidity, thermal fluctuations, freeze-thaw (lacob, 2008). The cysts are resistant to traditional preservation methods such as brining, smoking and drying of pork or game meat, respectively (Cironeanu \& Ispas, 2002). In Romania people usually preserve meat by freezing in fridges with temperature ranging between -15 and $-18^{\circ} \mathrm{C}$.

In the current European context, EC Regulation no. 2075/2005 of 5 December 2005, which mentions the specific rules for official controls of Trichinella in meat, states that "the pieces of meat with a diameter or thickness not exceeding $15 \mathrm{~cm}$ must be frozen in accordance to one of the following combinations of time and temperature: 20 days at $-15^{\circ} \mathrm{C}$, or 106 hours at $-18^{\circ} \mathrm{C}$, ensuring that the $T$. spiralis larvae are destroyed and the meat can be fit for human consumption (EC Regulation no. 2075/2005).

The purpose of this study was to check the resistance of Trichinella larvae in pork and wild boar meat, frozen at $-18^{\circ} \mathrm{C}$ for long periods of time and to test the viability of the larvae by experimental infection of the laboratory mice.

\section{Material and Methods}

\section{Experimental animals}

Twelve laboratory mice Biobase, of line BALB/ C BAGG/ Albino/ C strain, aged 30 days and average weight $25 \mathrm{~g}$ were used. There were three experimental and one control groups, each of them consisting of three mice. Maintenance and dietary requirements of the animals were constant throughout the experiment, ensuring biological comfort, according to the European standards in EC Directive no. 63/2010.

\section{Meat samples}

Infected meat samples originated from Veterinary and Food Safety Laboratory (VFSL) Vaslui, Romania, kept for a long period of time as control samples known their detailed data (place of origin, sampling, examination and submission date for storage in a freezer $\left(-18^{\circ} \mathrm{C}\right)$.

Sample 1 consisted of pork ribs and smoked sausage from a private household in Fălciu - Vaslui, preserved for 1021 days by freezing from January 29, 2009 to November 16, 2011.

Sample 2 consisted of pork ribs and intercostal muscles from a private household in Vaslui city, preserved for 328 days by freezing from December 23, 2010 to November 16, 2011.

Sample 3 consisted of wild boar intercostal muscles, hunted in the Hunting Field of Huși Forestry-Vaslui, preserved by freezing from February 21, 2011 to November 16, 2011, with a total period of freezing of 268 days.

Twenty-eight fragments were taken for each sample and placed on the compressor blade, clarified with $1 \%$ acetic acid solution and examined under a screen trichinelloscope. In sample 1 there were 4 infected fragments with one cyst, in each of them. There were 7 infected fragments with $1-3$ cysts in each of them in sample 2 , and 10 infected fragments were found in sample 3 with 1 to 4 cysts per fragment.

From each of those three samples (two from pork meat and one from wild boar meat) infected with Trichinella spiralis, were harvested $50 \mathrm{~g}$ and sent to the authorized Veterinary and Food Safety Laboratory (VFSL) Iași-Romania, Department of Parasitology, where Trichinella larvae were extracted by artificial digestion method (Gamble et al., 2000). The larvae were shipped to the European Reference Laboratory of the Higher Institute of Health, Rome, Italy for the genetic identification of the Trichinella species with multiplex polymerase chain reaction (PCR) method (Pozio and La Rosa, 2003) where it was confirmed that the larvae found in pigs and wild boar belong to the Trichinella spiralis species.

\section{Experimental Protocol}

The mice of group I, II and III were fed with $20 \mathrm{~g}$ muscle fragments or mincemeat of sample 1,2 and 3, respectively. After three days the remain food were collected from each mice group and weighed. In mice group I, II and III only $0.86 \mathrm{~g}, 5.04 \mathrm{~g}$ and 0.20 $\mathrm{g}$ food remained, respectively. Subsequently, the mice were fed daily with the like the animals of the control group.

Mice were observed daily. All the mice were euthanized with chloroform on the $80^{\text {th }}$ day of the experiment in accordance with the existing EU legislation (EC Directive no. 63/2010).

Tissues samples were collected from abdominal, intercostal, diaphragm and dorsal muscles of each mouse and deposited in $10 \%$ formaldehyde containers and were specifically processed for inclusion in paraffin. Fragments were sectioned at $5 \mu \mathrm{m}$, stained by Masson Trichrome methods (Hematoxylin Eosin Blue) and May Grünwald Giemsa. Examination and microphotography were performed by using a Leica DM 750 optical microscope, a Leica ICC 550 Camera and a Leica Application Suite (LAS), version 4.2 (Oct. 2012), for image retrieval. 


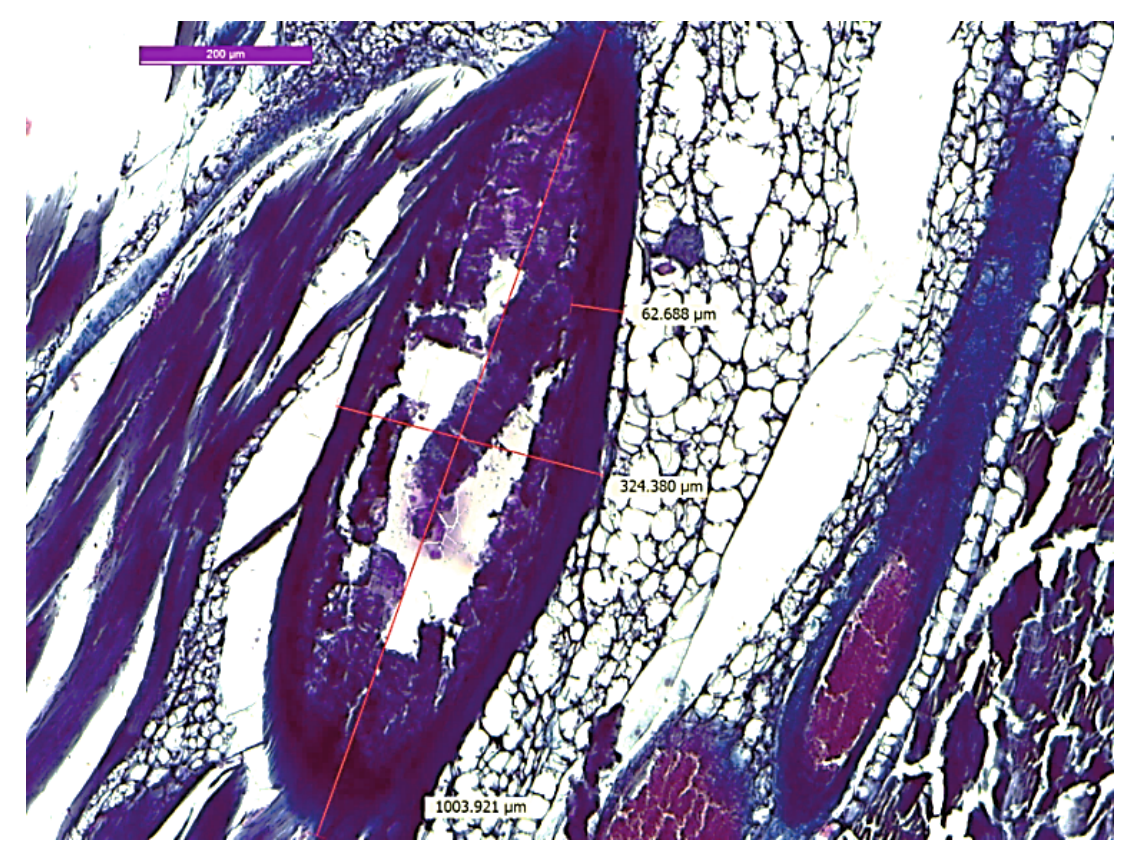

Fig. 1. Diaphragm striated muscle tissue at 80 days p.i. from a mouse fed with pork meat containing Trichinella cysts. The meat had been frozen for 1021 days (Spindle shaped cystic structure, thick and calcified wall with larvae fragments can be seen (stained with Hematoxylin Eosin Blue, 200x)

\section{Results}

The presence of cystic formations in variable number, depending on the lot was seen in muscular tissues of the experimental groups (Table 1).

Trichinella cysts were found in the abdominal and diaphragmatic muscles of all three mice from each group. In the intercostal muscle samples, Trichinella cysts were found in different amount between each group, while in the dorsal muscle samples were not found any Trichinella cysts from each group. No cystic formations were observed in the muscular tissue fragments of the control mice.

Mice in group one (I) had spindle shaped, $1003.9 \times 324.4 \mu \mathrm{m}$ sized cystic formations in their muscle tissues (Fig. 1). The wall was very thick $(62.69 \mu \mathrm{m})$ and calcified, there were larval fragments and amorphous debris inside of the cyst. A pronounced tendency to calcification from the poles of the cyst was noted. The cystic formations were disseminated throughout the diaphragm and abdominal muscle fragments.
Histological examination of the samples collected from mice of group two (II) showed cystic formations having $950.6 \times 356.1 \mu \mathrm{m}$ in size, which were well delimitated and disseminated in the muscle tissue, with or without fat cells to one of their poles (Fig. 2). The wall was thick, calcified, and its content was composed of amorphous debris. This kind of cystic formations was found in the abdominal and diaphragm muscle fragments.

Histological examination of the muscle samples taken from mice of group III revealed a higher number of variable-sized cystic formations, similar to those identified in samples of groups I and II. These cysts mainly disseminated in the abdominal muscles. The oval cystic formations $(736.7 \times 401.8 \mu \mathrm{m})$ had a well-structured wall, bounded by adjacent muscle tissue, containing marginal amorphous debris and around a larva-like structure (Fig. 3).

In other cases, cystic formations were almost round shaped (797.9 $\times 680.8 \mu \mathrm{m}$ ), well defined and in intimate contact with the adjacent muscle tissue. Inside the cyst, condensed marginal material and central cell debris and inflammatory cell infiltration was found (Fig. 4).

Table 1. Number of Trichinella cysts found in muscle samples collected from experimentally infected and control laboratory mice

\begin{tabular}{|c|c|c|c|c|c|c|c|c|c|c|c|c|}
\hline \multirow{3}{*}{$\begin{array}{l}\text { Group } 1 \\
\end{array}$} & \multicolumn{12}{|c|}{ Muscles of } \\
\hline & \multicolumn{3}{|c|}{ Abdominal } & \multicolumn{3}{|c|}{ Intercostal } & \multicolumn{3}{|c|}{ Diaphragm } & \multicolumn{3}{|c|}{ Dorsal } \\
\hline & 3 & 2 & 4 & 0 & 1 & 0 & 2 & 3 & 1 & 0 & 0 & 0 \\
\hline ॥ & 6 & 4 & 5 & 1 & 0 & 1 & 4 & 1 & 2 & 0 & 0 & 0 \\
\hline III & 9 & 10 & 7 & 2 & 1 & 1 & 1 & 3 & 2 & 0 & 0 & 0 \\
\hline Control & 0 & 0 & 0 & 0 & 0 & 0 & 0 & 0 & 0 & 0 & 0 & 0 \\
\hline
\end{tabular}

1 three mice /group

group I: mice fed with pork meat frozen for 1021 days at $-18^{\circ} \mathrm{C}$;

group II: mice fed with pork meat frozen for 328 days at $-18^{\circ} \mathrm{C}$;

group III: mice fed with wild boar meat frozen for 268 days at $-18^{\circ} \mathrm{C}$ 


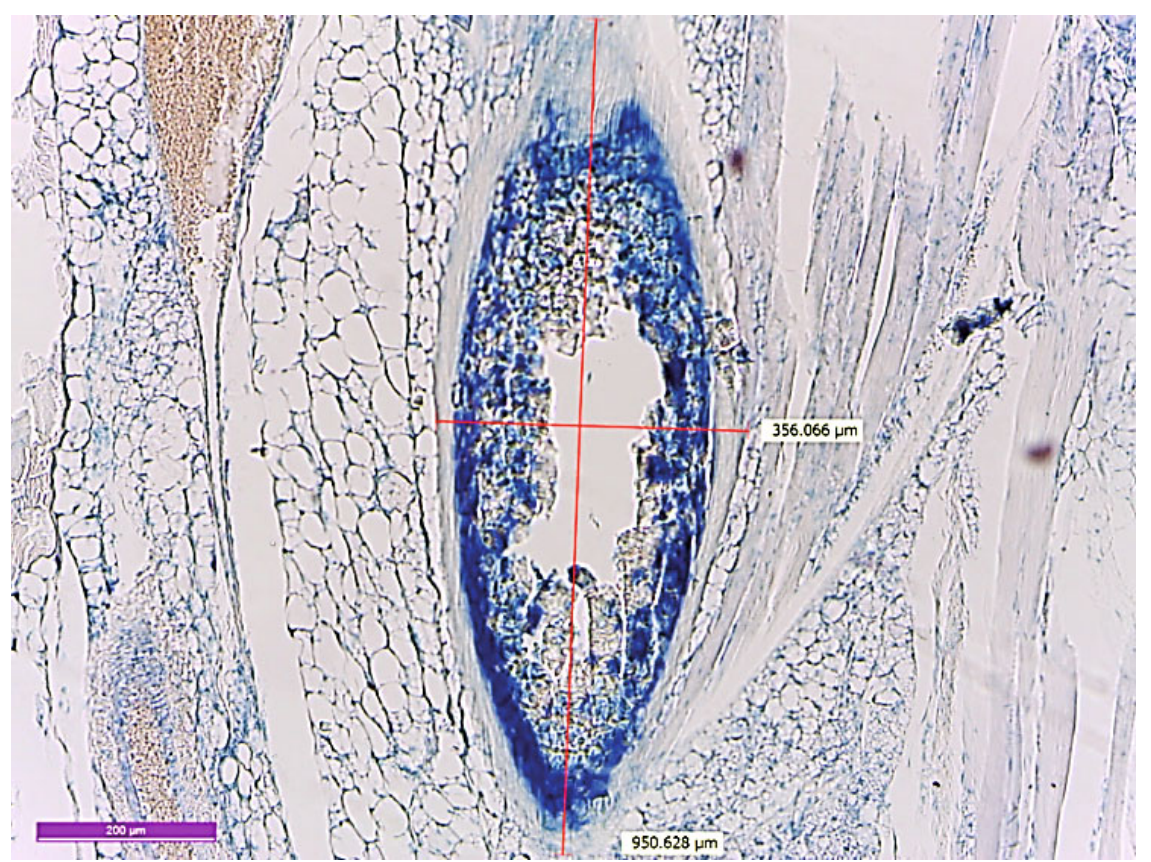

Fig. 2. Diaphragm striated muscle tissue at 80 days p.i. from a mouse fed with pork meat containing Trichinella cysts. The meat had been frozen for 328 days. (Spindle shaped cystic structure, thick and calcified wall and pole and amorphous debris can be seen (stained with May Grünwald Giemsa, 100x).

In some cases, the cystic formations had a dilated oval shape with broad poles, measuring $1164.9 \times 657.5 \mu \mathrm{m}$, with thickened and streamlined wall, and the content consisted of a dynamic and expanding cell population that occupies half of the cyst and extends like a "cleansing" action, to the other half, where cellular debris can be found (Fig. 5).

In the examined muscle tissue fragments, the number of cyst structures has varied from 0 in the dorsal muscles to 10 in the abdominal muscles (Table 1; Fig. 6).

\section{Discussion}

Experimental infection of laboratory mice with pork and wild boar meat containing Trichinella cysts and frozen at $-18{ }^{\circ} \mathrm{C}$ for a time ranging from 268 days to 1021 days, caused Trichinella infections in all groups of mice. Trichinella cysts were identified in their muscles, at 80 days post infection. The results demonstrate the extraordinary ability of Trichinella larvae to withstand normal freezing $\left(-18^{\circ} \mathrm{C}\right)$ and retain viability for long periods.

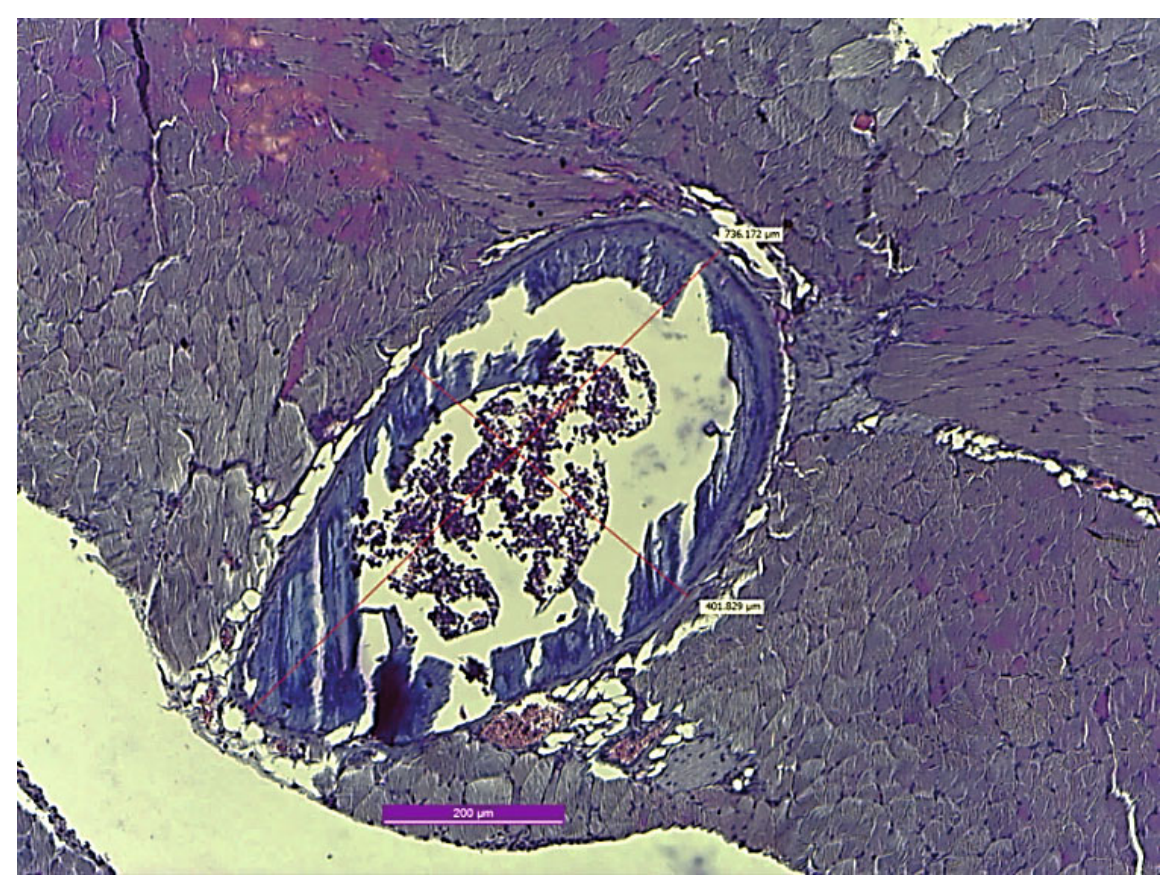

Fig. 3. Abdominal striated muscle tissue at 80 days p.i. from a mouse fed with wild boar meat containing Trichinella cysts. The meat had been frozen for 268 days. (Oval shaped cystic structure, well defined wall with marginal, wall adhesive amorphous content and central inflammatory infiltrate can be seen - stained with Hematoxylin Eosin Blue, 100x). 


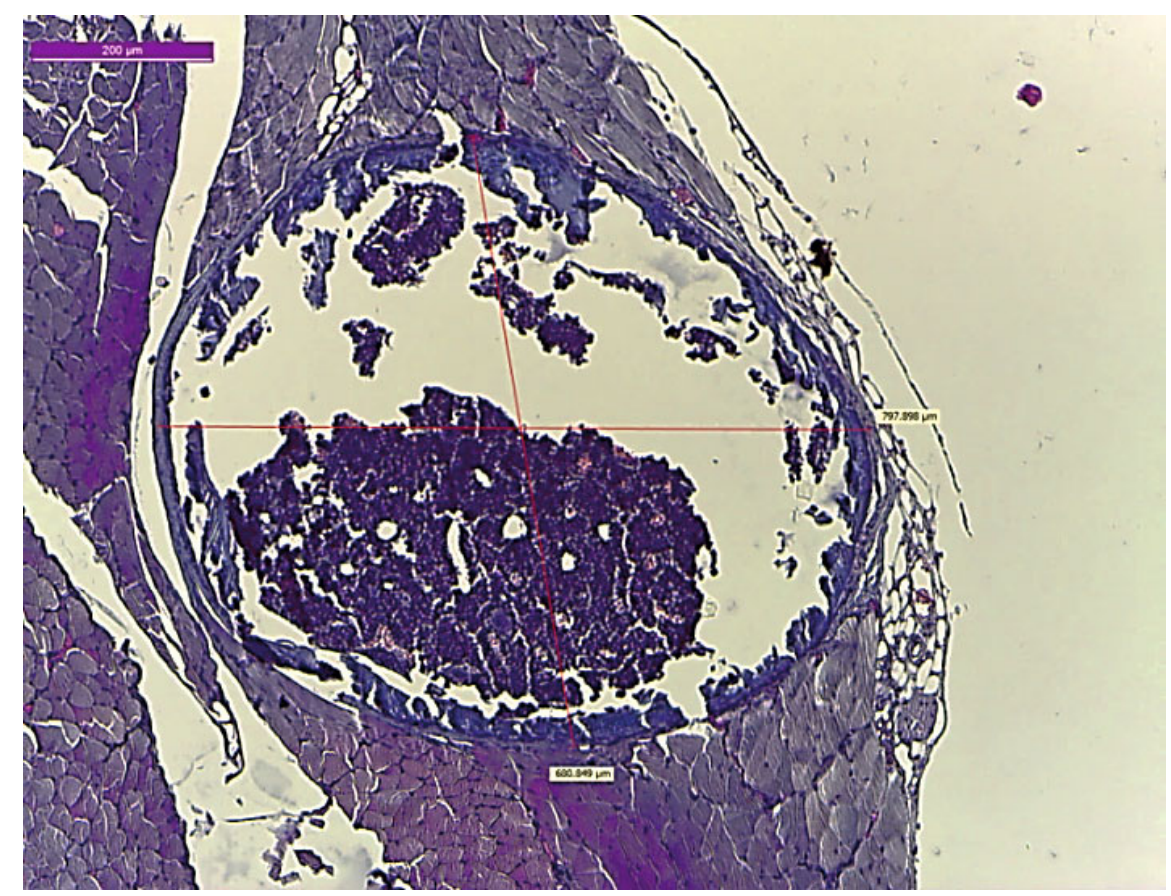

Fig. 4. Abdominal striated muscle tissue at 80 days p.i. from a mouse fed with wild boar meat containing Trichinella cysts. The meat had been frozen for 268 days. (Round shaped cystic structure, mantained wall integrity, with marginal amorphous content and central cell debris can be seen - stained with Hematoxylin Eosin Blue, 100x)

The appearance of the fat cells at the poles of the cystic formations replaces the damaged and destroyed muscular tissue. The activation of the immune response was seen by the presence of inflammatory cell populations, lymphocytes, and eosinophils. This cell mixture infiltrated and focused on the cystic wall, forming inflammatory infiltrate which induced the local inflammatory process as previously reported by Cironeanu and Ispas (2002).

The resistance of Trichinella larvae encapsulated in the striated muscle at temperature has been documented by others. For example, negative temperatures have been used to differentiate between T. spiralis and T. nativa species. Smith (1983) showed that
T. spiralis in musculature do not survive 48 hours post refrigeration at $-32{ }^{\circ} \mathrm{C}$, while $T$. nativa will survive 72 hours and longer at the same temperature.

Also, Ooi et al. (1986) showed that T. spiralis larvae originated from the polar bear survived for a month at $-20{ }^{\circ} \mathrm{C}$, probably because it belonged to $T$. nativa. The larvae of $T$. spiralis in the muscle of spontaneously infected polar bear, wolverine, arctic fox and marten have been reported to be viable even after storage at $-15^{\circ} \mathrm{C}$ for more than five months. That $T$. spiralis in polar bear is still alive even after freezing at $-20^{\circ} \mathrm{C}$ implies the disposition of infected carcasses that must be handled with care.

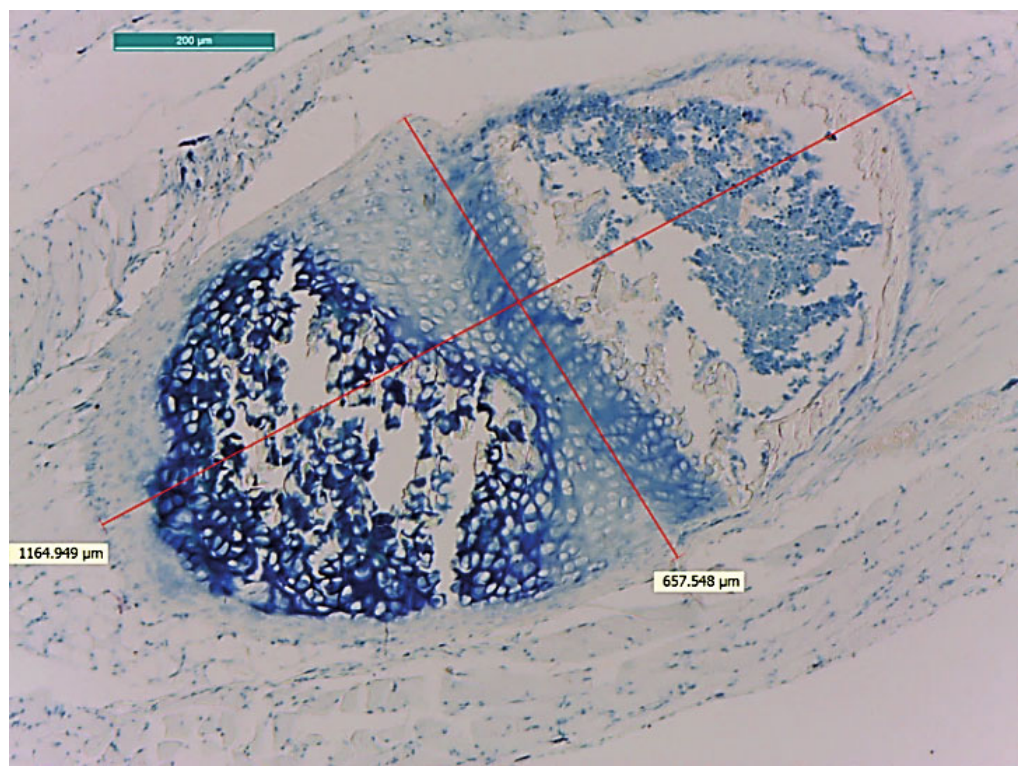

Fig. 5. Abdominal striated muscle tissue at 80 days p.i. from a mouse fed with wild boar meat containing Trichinella cysts. The meat had been frozen for 268 days. (Oval shaped cystic structure, well defined, thickened wall, with debris and active inflammatory cell population inside can be seen - stained with May Grünwald Giemsa, 200x) 


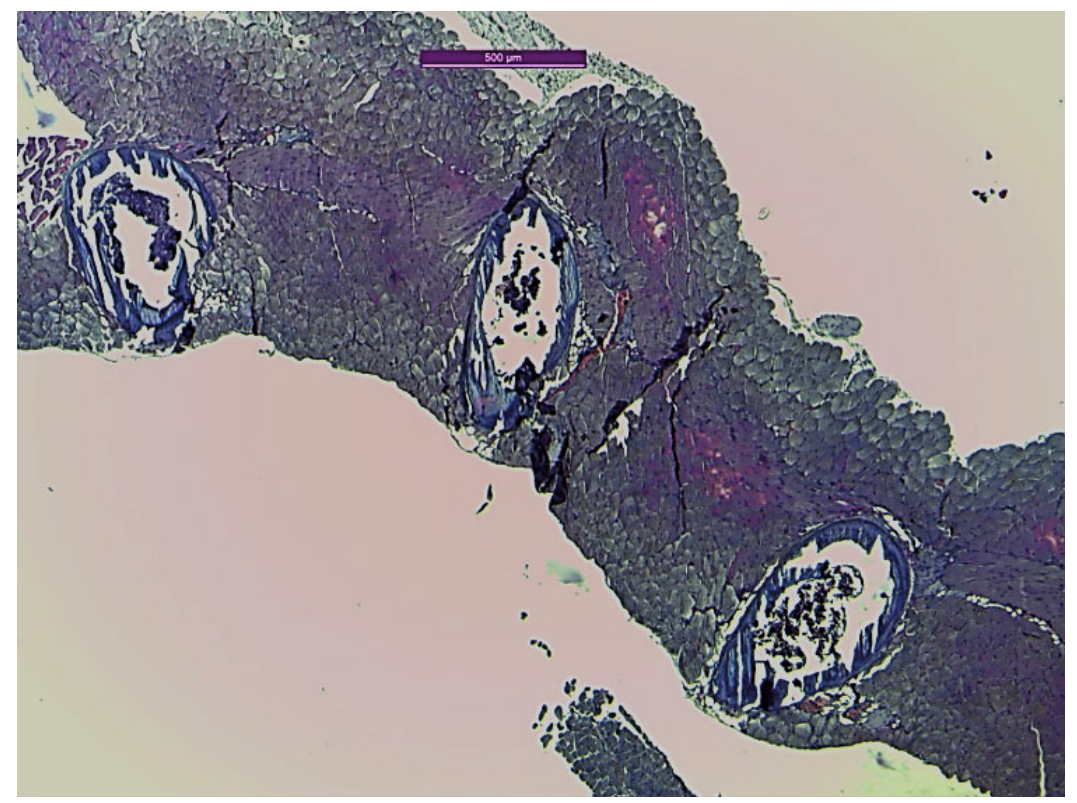

Fig. 6. Abdominal striated muscle tissue at 80 days p.i. from a mouse fed with wild boar meat containing Trichinella cysts. The meat had been frozen for 268 days. Many cystic structures can be seen (stained with Hematoxylin Eosin Blue, 46x)

The results reported here highlight the risk of human infection by eating meat that has been frozen even for a long period of time at $-18{ }^{\circ} \mathrm{C}$, due to incomplete thermal killing of the parasite. The findings of this study strongly support changing the recommended combination of time and temperature used in freezing pork and wild boar meat infected with $T$. spiralis as specified in EU Regulations and a reassessment of the risk for consumers.

In the long term, the risk of infection is best removed by unconditionally eliminating the Trichinella infected meat from human consumption.

It should be emphasized that infected samples used in this study came from an area where $T$. spiralis is found not only in household pigs, but also in the wild boar from the sylvatic environment. The different sources of infection for humans and other susceptible animals, spread over a broad geographical area must be taken into consideration when considering new health guidance protocols.

The findings have important implications for the storage of pork and wild boar meat. Consumers should be made aware of the need to cook meat thoroughly even if the meat has been frozen for a long period. Freezing alone does not render the meat safe to eat.

\section{Acknowledgements}

I thank to Dr. Costel Niță, Veterinary and Food Safety Department Vaslui, for the provision of infected material, to Ms. Eng. Gabriela Răileanu, discipline of Pathology, Faculty of Veterinary Medicine lași, who prepared the histological samples of muscle tissue taken from all batches of mice, to Dr. Elena Ișan and Dr. Stelian Asiminei from Veterinary and Food Safety Laboratory lași, who ensured the extraction of Trichinella larvae by artificial digestion method.

I am grateful to Dr. Edoardo Pozio from Istituto Superiore di Sanita, Department of Infectious, Parasitic and Immunomediated Diseases in Rome, Italy for organizing the transport and analysis of samples in order to identify the Trichinella spiralis larvae used in this experiment.

\section{References}

Blaga, R., Gherman, C., Cozma, V., Zocevic, Al., Pozio, E., BoIREAU, P. (2009): Trichinella species circulating among wild and domestic animals in Romania. Vet. Parasitol., 159: 218 - 221. DOI: 10.1016/j.vetpar.2008.10.034

Cironeanu, I., Ispas, T.A. (2002): All about trichinellosis. Ed. Mast, București, Romania, 190 pp. (In Romanian)

Dupouy-CAmet, J. (2000): Trichinellosis: a worldwide zoonosis. Vet. Parasitol., 93: 191 - 200. DOI: S0304-4017(00)00341-1

European Community Commission (2005): Commission Regulation (EC) no. 2075/2005 of 5 December 2005, regarding the specific rules on official controls for Trichinella spp. in meat. European Community Commission, taking into account the Treaty for the establishment of the European Community (OJ L 338, 22.12. 2005, p. 60) Annex II Treatment by freezing; B. Freezing Method 2; Freezing Method 3

Farina, F., Scialfa, E., Bolpe, J., Pasqualetti, M., Rosa, A., RIBICICH, M. (2012): Study of Trichinella Spp in Rodents that Live Near Pig Farms in an Endemic Region of the Province of Buenos Aires, Argentina. J. Bacteriol. Parasitol., 3: 4. DOI: 10.4172/21559597.1000140

Gamble, H.R., Bessonov, A.S., Cuperlovic, K., Gajadhar, A.A., Van Knapen, F., Noeckler, K., Schenone, H., Zhu, X. (2000): International Commission on Trichinellosis: recommendations on methods for the control of Trichinella in domestic and wild animals intended for human consumption. Vet. Parasitol., 93, 393 - 408 IACOB, O. (2008): Research regarding the resistance of Trichinella spiralis larvae in pork meat subjected to repeated freazing-defreazing. $J$. EcoAgriTourism, 4 (1 - 2): 208 - 212

KaPEL, O. M. C. (2005): Changes in the EU legislation on Trichinella inspection-New challenges in the epidemiology. Vet. Parasitol., 132 189-194. DOI: 10.1016/j.vetpar.2005.05.055

Krivokapich, S.J., Prous, C.L., Gatti, G.M., Confalonieri, V., Molina, V., Matarasso, H., Guarnera, E. (2008): Molecular evi- 
dence for a novel encapsulated genotype of Trichinella from Patagonia, Argentina. Vet. Parasitol., 156: 234 - 240. DOI: 10.1016/j. vetpar.2008.06.003

Murrell, D.K, Lichtenfels, R.J., Zarlenga, S.D., Pozio, E. (2000): The systematics of the genus Trichinella with a key to species. Vet. Parasitol., 93: 293 - 307. DOI: S0304-4017(00)00347-2

Neghină, R., Neghină, A. M., Marincu, I. (2012): Trichinellosis in hospitalized patients from a Romanian endemic area, 2007-2009. Clin. Microbiol. Infect., 2012; 18: 86 - 90. DOI: 10.1111/j.14690691.2011 .03573

Oivanen, L., Mikkonen, T., Haltia, L., Karhula, H., Saloniemi, H., SukuRA, A. (2002): Persistence of Trichinella spiralis in rat carcasses experimentally mixed in different feed. Acta vet. Scand., 43: 203 - 210. DOI: 10.1186/1751-0147-43-203

Ool, K. H., Kamiya, M., Ohbayashi, M., Nakazawa, M. (1986): Infectivity in rodents and cold resistance of Trichinella spiralis isolated from pig and polar bear, and T. pseudospiralis. Jpn. J. Vet. Res., 34: 105 - 110. http://hdl.handle.net/2115/2975

Paraličová, Z., DubinskÝ, P., Kristian, P. JarČušKa, P. (2013): Unusual clinical course of trichinellosis with relapse. Helminthologia, 50, 2: 142 - 146, DOI: 10.2478/s11687-013-0123-5.

Pozıo, E. (2001): New patterns of Trichinella infections. Vet. Parasitol., $98,133-148$
Pozıo, E., LA Rosa, G. (2003): PCR-derived methods for the identification of Trichinella parasites from animal and human samples. Methods Mol. Biol., 216, 299 - 309

Pozıo, E. (2005): The broad spectrum of Trichinella hosts: From cold-to warm-blooded animals. Vet. Parasitol., 132 (2005) 3 - 11. DOI: 10.1016/j.vetpar.2005.05.024

Pozio, E., Zarlenga, S. D. (2005): Recent advances on the taxonomy, systematics and epidemiology of Trichinella. International Journal for Parasitology 35 (2005) 1191-1204. DOI:10.1016/j.jpara.2005.07.012

Pozio, E., Murrell, D. K. (2006): Systematics and epidemiology of Trichinella. Adv. Parasitol., 63: 367 - 439. DOI: 10.1016/S0065308X(06)63005-4

Pozıo, E. (2007): World distribution of Trichinella spp. Infections in animals and humans. Vet. Parasitol., 149: 3 - 21. DOI: 10.1016/j. vetpar.2007.07.002

Pozio, E., Hoberg, E., La Rosa, G., Zarlenga, S. D. (2009): Molecular taxonomy, phylogeny and biogeography of nematodes belonging to the Trichinella genus. Infect. Genet. Evol., 9: 606 - 616. DOI: 10.1016/j.meegid.2009.03.003

Sмiтн, J. H. (1983): Differentiation of Trichinella spiralis spiralis and Trichinella spiralis nativa Based on Resistance to Low Temperature Refrigeration. Can. J. Comp. Med., 47: 501 - 502 